\title{
Application of Multimedia Education Technology in English Teaching
}

\author{
Cheng Peng ${ }^{1}$ and Qu Hui ${ }^{2}$ \\ ${ }^{1}$ Training Department, Engineering University of PAP, Xi'an 710086, China \\ ${ }^{2}$ School of Science, Engineering University of PAP, Xi'an 710086, China
}

Keywords: multimedia, traditional English teaching, multimedia teaching, Teachers' Role.

\begin{abstract}
The rapid development of multimedia technology and network technology to college English teaching has brought great changes. Because multimedia assisted English teaching differs from traditional teaching and, therefore, should be to locate multimedia teachers and students as a means of transmitting information, and how to apply should depend on the actual level of teachers and students and requirements. It's not teaching methods, how to improve equipment, advanced, but whether to update the concept of teaching, whether the method is more vitality, whether the effect is better. Integration of information technology and English teaching is to promote the improvement and development of traditional teaching.
\end{abstract}

\section{Introduction}

Modern educational technology in the multimedia assisted instruction as an innovative teaching methods, the text, graphics, video, sound, animation and a variety of multimedia educational software to introduce the teaching practice, has greatly enriched the teaching methods to optimize the structure of the English classroom, make teaching interesting and rich, contextual, and thus help improve the quality of teaching, multimedia teaching to make teaching content from the abstract becomes intuitive. The use of multimedia teaching mode changes the environment, process, mode and method of teaching and learning, and it also has a profound influence on the conversion of English teacher's role. Teachers' role is the behavior of teachers in the school environment and the formation of the sum of the norms of behavior. Traditional Education Ideas for Teachers' Professional judgment is preaching, Tuition, FAQ [1]. Therefore, English language teachers in the teaching process is completely dominant, the pronunciation, grammar or vocabulary as the main objective of teaching. In traditional teaching, the role of teachers is another examiner. Teachers should participate in assessing the performance of the student's classroom, but also to write papers test students' language communication skills. At the same time, teachers also error correction, resulting in the classroom students are not active enough, and daring to speak for fear of making mistakes, affecting the realization of English communication tool functionality [2]. In the traditional English teaching, the teacher's role and the teaching mode make the students accept the book knowledge passively, but lack the ability of autonomous learning and the opportunity to communicate with others. In the multimedia teaching environment, to achieve the transfer from teacher-centered to student-centered, give full play to both teachers and students enthusiasm, focus on interactive teaching; To students individualized independent study based, supplemented by teacher face to face, to achieve the combination of a variety of teaching methods, English teaching without time and place restrictions towards personalized learning, active learning direction. Therefore, English teachers' role in teaching and are bound to change, and given new features [3].

\section{Multimedia technology development}

\subsection{Introduction to Multimedia Technology Teaching}

The so-called multimedia is the integration of a human-machine interactive information exchange and dissemination of media two or more media, the media used include text, image, graphics, Anime, audio, and video. The multimedia teaching as the various elements of multimedia teaching according to the requirements, and through a combination of organic or projector projection screen is displayed, press the need to add sound cooperation, and the use of interactions between the computer to complete the process of teaching or practice. Multimedia technology, is a necessary means among our 
teaching, multimedia teaching process, mainly authorware, flash or powerpoint-medium primary "weapon" to read online, query data, email sending job, answering, supplemented [4].

With the development of computer science and technology, artificial intelligence technology and virtual simulation technology to use more and more of the multimedia teaching them to go. Which, for the use of artificial intelligence and virtual technology, on the one hand, teachers will provide strong support for teaching, such as teaching resources, student teaching management [5]. On the other hand, students are using this technology, you can reference provided by the system, developed for their own autonomy, individualized learning programs, while also greatly improved the efficiency of learning.

\subsection{Situation development of multimedia technology}

With the development and progress of the information age, the implementation of the teaching reform, the traditional way of English mathematics has been unable to meet the requirements of modern education. Multimedia provides us overcome the drawbacks of traditional teaching new teaching methods [6]. The use of multimedia technology, demonstration experiment phenomenon difficult to observe in practice, you can display three-dimensional graphics from every angle, you can make some abstract and difficult concepts into specific observable picture, graphics, can dynamically show some changes the process can also be some changes in the process carried out in stages demo and so on. This is undoubtedly the reform of classroom teaching injected fresh blood, to change the traditional classroom teaching model provides a new idea [7]. Multimedia content-rich, focused, break through the difficulties, according to the needs of teaching, the creation of teaching situations, guide the students to break thought disorder, so that the original hard teaching activities full of charm, mobilize the enthusiasm of students, to stimulate student interest in learning [8]. If, however, the excessive use of multimedia teaching, will dominate, contrary to the multimedia "assist" the purpose of teaching, so that students fly in the classroom is not intended to lead to excessive attention to classroom teaching, saying the failure to Table and where, not to mention real play the subjectivity of students.

\subsection{Relationship between Multimedia Teaching and Traditional English Teaching}

Traditional English teaching is relative in terms of multimedia teaching. Mentioned traditional English teaching, a lot of people and it is very natural to "focus on awareness, instill closed; poured into the formula, cramming; a piece of chalk, a blackboard, a book," and other such words associated with it complete denial. These words reflect the major shortcomings of traditional English teaching: first, time-consuming, laborious, the effect is poor; second, the amount of information is limited; third, a single media, it is difficult to mobilize students to a variety of sensory stimulation. But this is only our deviation from traditional English teaching understanding [9]. Not interested in teaching traditional teaching ignored, blindly "duck"; in turn, it is not as long as the use of multimedia teaching can stimulate students' interest in learning, you can use the same riddle, "task" teaching and storytelling, also can be mobilized Teaching " subject "students, to better serve the students and to promote the development of each student, to strengthen the two-way interaction between teachers and life and life force, shortening the distance between teachers and students, it is conducive to emotional exchanges. In the traditional English classroom teaching, teachers can maximize the initiative. Teachers with experience, love, personal charisma to infect students, arouse their curiosity and help them establish the correct motivation.

Multimedia English teaching and traditional English teaching in relation to the presence of each other with their respective advantages, but they are not antagonistic, but complementary, complementary and mutually reinforcing. Denial and abandonment and Multimedia English Teaching relatively traditional English teaching is wrong. Only handle the relationship between the two, in order to better develop students' listening, speaking, reading and writing skills [10]. As the organizer of the class teachers, teaching materials, and pay attention to the communication and students' emotion. But learning English is not the only resource materials, teaching content can not be limited to textbooks, teachers in guiding students to do the exercises should use appropriate means, multimedia is a good helper, is a traditional English teaching materials using a good supplement. 


\section{Multimedia Assisted English Teaching in schools in usage}

First of all, multimedia classroom teaching is a new way of learning, which is adapted to the needs of the development of the times. Secondly, the hot, the current teaching reform of multimedia teaching exploration and research but belongs to each one according to his lights, most people hold a favorable attitude, some people see in the practical application of multimedia application is inadequate and unreasonable and puts forward the improvement measures, but not on how to better use of multimedia in the classroom teaching to form a unified point of view. Traditional English teaching in schools still exist, the purpose of teaching, teaching efficiency, effectiveness and teaching to meet student needs can not be ignored. In order to understand the real situation of multimedia English teaching, we all schools 100 teachers and 90 students were investigated and analyzed in order to understand the situation on the basis, reflect and propose possible solutions, try to explore multimedia English ways of teaching, found in the multimedia assisted English teaching correct positioning of teachers, so as to achieve the purpose of teaching in a multimedia environment, to better serve the students.

\subsection{Teacher}

\subsubsection{The basic situation of English Teachers}

The age and the highest educational level of English teachers are directly related to the application of multimedia. On the age and the highest academic degree of English teachers see Table 1 and table 2.

Table 1 The basic situation of the teachers being investigated

\begin{tabular}{c|c|c|c|c|c}
\hline $\begin{array}{c}\text { Age (years } \\
\text { old) }\end{array}$ & $\begin{array}{c}\text { Number of } \\
\text { people }\end{array}$ & Percentage & $\begin{array}{c}\text { School age } \\
\text { (years) }\end{array}$ & $\begin{array}{c}\text { Number of } \\
\text { people }\end{array}$ & Percentage \\
\hline $20-30$ & 23 & $23 \%$ & $1-5$ & 37 & $37 \%$ \\
\hline $30-40$ & 36 & $36 \%$ & $6-10$ & 39 & $39 \%$ \\
\hline $40-50$ & 32 & $32 \%$ & $11-15$ & 6 & $6 \%$ \\
\hline$\geqslant 50$ & 9 & $9 \%$ & $16-20$ & 6 & $6 \%$ \\
\hline Total & 100 & $100 \%$ & $\geqslant 20$ & 12 & $12 \%$ \\
\hline & & & Total & 100 & $100 \%$ \\
\hline
\end{tabular}

Table 1 shows that English teachers aged over 20 years old accounted for 23\%, 36\% in their thirties, forties of 32\%, while only 9\% over 50 years old. English teacher seniority within five years accounted for 37\% to 6--10 years accounted for 39\%, to 11--15 years accounted for 6 percent to 16--20 years accounted for 6 percent to more than 20 years accounted for $12 \%$. From two sets of data show that more and more English teachers tend to be younger. By comparison, young teachers are more qualified to use multimedia technology, because they are more likely to acquire more relevant knowledge and skills than older teachers.

Table 2 English Teachers highest level of education

\begin{tabular}{c|c|c}
\hline Education level & Number of people & Percentage \\
\hline Doctor's degree & 11 & $11 \%$ \\
\hline Master's degree & 46 & $46 \%$ \\
\hline Bachelor's degree & 38 & $38 \%$ \\
\hline College degree & 5 & $5 \%$ \\
\hline Total & 100 & $100 \%$ \\
\hline
\end{tabular}

Table 2 shows that 5\% of English teachers are college educated, 11 percent of teachers have a doctorate,, Most teachers (46\% of master's degree, a bachelor's degree 38\%) have obtained a master's degree and bachelor's degree. In recent years, Chinese government carried out a series of policies to attract some of the best college graduates, and even a growing number of graduate and doctoral are willing to put into English teaching career to an increasing number of qualified English teachers with good educational background, will undoubtedly accelerate and optimize the complementary role of multimedia in English teaching. 


\subsubsection{The application frequency of multimedia technology in English teaching and the teacher's} attitude

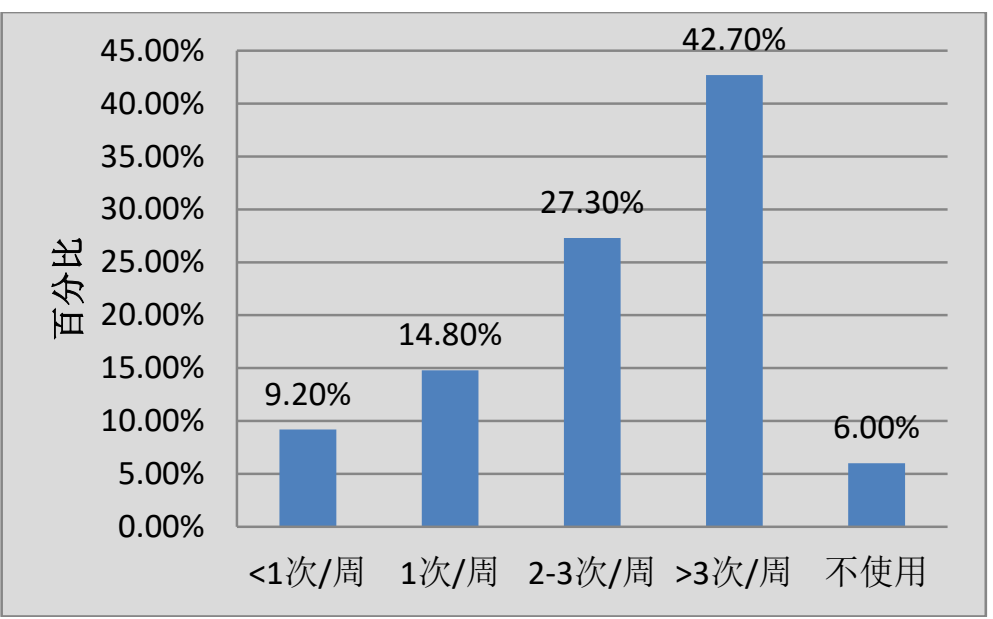

Fig. 1 The application of multimedia technology in English Teaching

Fig. 1 shows that the frequency of application of multimedia technology in English teaching. This indicates that 9.2 percent of English teachers in the use of multimedia teaching less than once a week, $14.8 \%$ of teachers using multimedia teaching only once a week, $27.3 \%$ of teachers who use multimedia teaching two or three times one week, $42.7 \%$ of teachers use it every week three times or more, and still has $6 \%$ of teachers never use multimedia teaching. Thus, most teachers can use multimedia teaching; some teachers use multimedia in hearing only part time or import content, leaving enough time to explain the text and grammar. Some teachers will be based on actual demand, will use vivid pictures and flash, so that multimedia plays a supporting role in teaching, it can be additional information to supplement teaching, in order to effectively attract students' interest in learning. However, teachers in the use of multimedia technology and the level of proficiency varies, which also restricted the number of teachers use multimedia in English teaching.

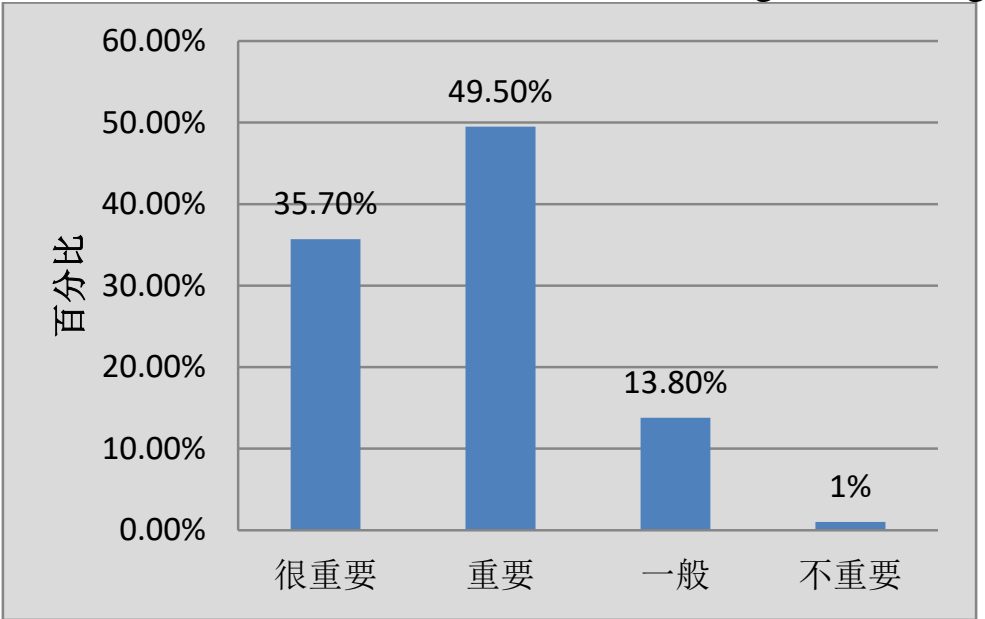

Fig.2 School teachers' attitudes multimedia in English teaching

Fig. 2 shows that English teachers $85.5 \%$ (very importan 35.7\%t +important $49.5 \%$ ) who agreed to play multimedia in English teaching with a very important or important role, 13.8\% of teachers, hold a neutral view on multimedia, and there are still $1.0 \%$ of teachers noted that multimedia technology is not very important in English teaching. It can be inferred that most teachers have a favorable impression of the multimedia classroom, likes, indicating that multimedia as a teaching tool for teaching indeed play a significant role in the English classroom, greatly promoted the modern English teaching. The correct ideas and beliefs and dominant in their teaching behavior may do great help promote modern teaching methods. At the same time, there are some teachers in the use of multimedia teaching concept behind this will affect the outcome of the application of multimedia teaching. 


\subsubsection{Teacher evaluation of multimedia effects}

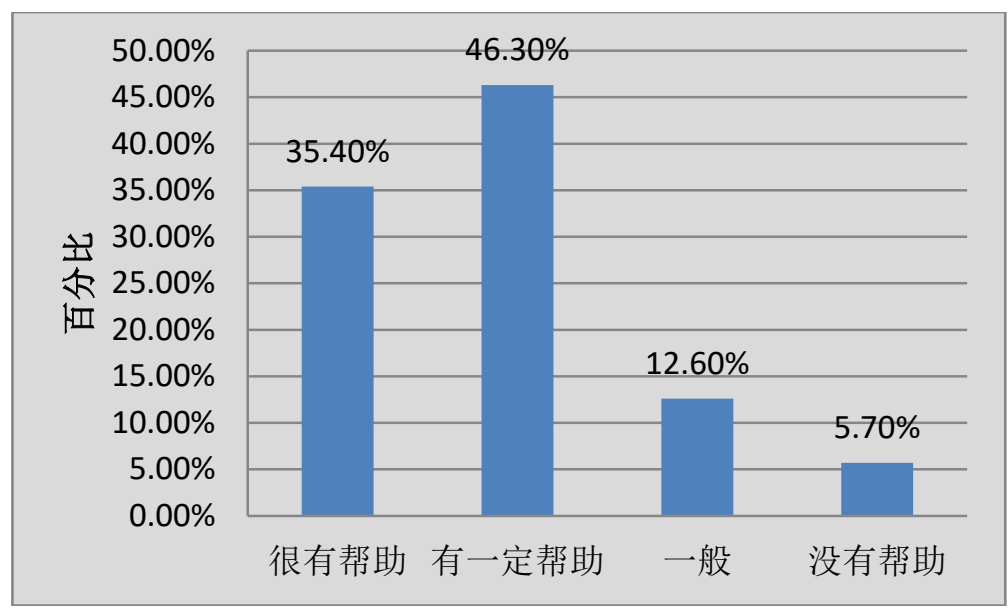

Fig.3 Teacher evaluation of multimedia effects

Fig. 3 shows that $81.7 \%$ of English teachers (helpful 35.4\%+some helpful $46.3 \%$ ) represents the multimedia help improve English teaching efficiency, even $35.4 \%$ of teachers think that multimedia applications can improve English teaching. We can not ignore the fact that there are $5.7 \%$ of teachers think that media can not improve teaching effectiveness. This may be due to the incorrect teaching idea and the attitude of the multimedia to the multimedia teaching advantage. Therefore, teachers should correctly understand and develop the attitude of the media, the use of multimedia technology advantage, improve teaching effectiveness.

\subsubsection{Method for English teachers to obtain courseware}

Table 3 courseware sources (multiple choice, 100)

\begin{tabular}{c|c|c|c|c}
\hline Classification & Produce their own & Download & Group share & $\begin{array}{c}\text { Learn from others of } \\
\text { their own modifications }\end{array}$ \\
\hline $\begin{array}{c}\text { Number of } \\
\text { people }\end{array}$ & 86 & 58 & 43 & 39 \\
\hline Percentage & $86 \%$ & $58 \%$ & $43 \%$ & $39 \%$ \\
\hline
\end{tabular}

Table 3 shows that the method of English teachers are multimedia courseware. From the source courseware, teachers mainly depends on their own, download, share and learn from the group courseware relatively small proportion of others. This shows that the teaching and research culture and set of equipment is not very strong or a mere formality, colleagues in the teaching can not constitute a real sense of helping each other. There are a lot of teachers think that multimedia teaching preparation for a long time, a waste of time and effort, and share and download the group is likely to cause the individual teacher does not think, does not prepare lessons and copying, no personality is concerned. This also shows that teachers courseware production capacity needs to be improved.

\subsubsection{English teaching multimedia applications}

Table 4 multimedia applications (multiple choice, 100)

\begin{tabular}{c|c|c|c|c|c}
\hline Favorite Programs & Word & Powerpoint & Frontpage & Flash & Authorware \\
\hline Number of people & 76 & 92 & 0 & 20 & 5 \\
\hline Percentage & $76 \%$ & $92 \%$ & $0 \%$ & $20 \%$ & $5 \%$ \\
\hline
\end{tabular}

Table 4 shows, in English teaching, word and Powerpoint are the two most frequently used programs. Powerpoint in the use of sound and animation more flexibility, better suited to lead class, open class is frequently used programs. Therefore, it can be seen from Table 4 to get more English teachers of all ages. When using a web view, word and pictures can add a background, set the font size bigger, is a good electronic blackboard, and by the font anti-white, with the time change, it is suitable for training and presentations, and the flexibility to modify. Most teachers have realized the word flexible, time-saving advantages and applications of the program, and some teachers have not found the benefits of word and apply it in the classroom teaching of foreign languages, indicating that the level of technology is also part of the English Teachers some behind. 
Table 5 multimedia use (multiple choice, 100)

\begin{tabular}{c|c|c|c|c|c|c}
\hline Teaching type & $\begin{array}{c}\text { Lesson } \\
\text { guide }\end{array}$ & $\begin{array}{c}\text { Language point } \\
\text { explanation }\end{array}$ & Exercise & Grammar & Vocabulary & $\begin{array}{c}\text { Additional } \\
\text { knowledge }\end{array}$ \\
\hline $\begin{array}{c}\text { Suitable for } \\
\text { multimedia class }\end{array}$ & $94.6 \%$ & $37.8 \%$ & $33.4 \%$ & $29 \%$ & $49.3 \%$ & $67.4 \%$ \\
\hline $\begin{array}{c}\text { Word application } \\
\text { class }\end{array}$ & $3.3 \%$ & $43.2 \%$ & $56.3 \%$ & $35.8 \%$ & $49.8 \%$ & $31 \%$ \\
\hline $\begin{array}{c}\text { Powerpoint } \\
\text { application class }\end{array}$ & $85.4 \%$ & $13.1 \%$ & $5.9 \%$ & $9.4 \%$ & $15.9 \%$ & $44.3 \%$ \\
\hline
\end{tabular}

Table 5 shows, the most suitable type of multimedia teaching guide teaching courses and supplementary materials. According to the above mentioned features of word and Powerpoint, Powerpoint English teachers will mainly attract students with interest in the pilot class, the percentage share of its options are: pilot courses 85.4\%, 13.1\% explain language points, 5.9 Exercises \%, 9.4\% grammar, vocabulary, $15.9 \%, 44.3 \%$ additional knowledge. Word is mainly used in exercises and on the explanation: guide class $3.3 \%$, language point to explain $43.2 \%$, exercise $56.3 \%$, grammar $35.8 \%$, vocabulary $49.8 \%$, additional knowledge $31 \%$.It can be seen in addition to word usage guide and supplementary courses outside the knowledge of other aspects than Powerpoint, this may be due to the word of the production of more time and effort.

In the actual teaching process, some teachers will talk about the contents of all hit the screen, doing so can cause learning of focus, not a solid grasp of knowledge, teachers ignored the adverse consequences of textbook content mining. Therefore, preparation of multimedia teaching is important, teachers must handle the relationship between the human brain and the electronic blackboard; attention to classroom capacity moderate, not exhaustive; by fonts, images and colors to highlight the important difficulties.

\subsection{Student}

\subsubsection{Students' attitudes toward multimedia English teaching}

Table 6 Student Attitude (multiple choice, 90) of Multimedia English Teaching

\begin{tabular}{c|c|c|c|c|c}
\hline Classification & $\begin{array}{c}\text { Like English } \\
\text { Multimedia } \\
\text { Teaching }\end{array}$ & $\begin{array}{c}\text { The use of } \\
\text { multimedia } \\
\text { helps develop } \\
\text { interest }\end{array}$ & $\begin{array}{c}\text { Multimedia } \\
\text { teaching helps } \\
\text { to develop the } \\
\text { thinking brain }\end{array}$ & $\begin{array}{c}\text { Each class } \\
\text { should use } \\
\text { multimedia }\end{array}$ & $\begin{array}{c}\text { Multimedia } \\
\text { can not after } \\
\text { writing on the } \\
\text { blackboard }\end{array}$ \\
\hline $\begin{array}{c}\text { Number of } \\
\text { people }\end{array}$ & 86 & 84 & 82 & 49 & 25 \\
\hline Percentage & $95.6 \%$ & $93.3 \%$ & $91.1 \%$ & $54.4 \%$ & $27.8 \%$ \\
\hline
\end{tabular}

Table 6 shows that students still like multimedia English teaching, because it can enrich students learning English fun, help develop interest in learning English and brain thinking, but this is largely refers to the sound and image integrated, while the use of audio-visual. However, there are many students simply reflect audiovisual students will only cause visual fatigue, attention, and even sleep, can not do the interaction between teachers and students, classroom monotonous, student motivation to learn decline, classes no sense of urgency. Sometimes teachers aside to let students listen, while some of the pictures displayed on the big screen, this result will only lead to student distraction, listening and watching will not achieve the intended educational purposes, and not conducive to the students to take notes. If you focused on the blackboard, the students will be impressed, so writing on the blackboard is not replaced with a multimedia screen. Complete with screen instead of blackboard affects advantage of multimedia in teaching to help us solve difficult problems. 


\subsubsection{Application of Multimedia in English Classroom}

Table 7 Application of Multimedia in English Classroom (multiple choice, 90)

\begin{tabular}{c|c|c|c|c|c}
\hline $\begin{array}{c}\text { Multimedia class } \\
\text { to do the most }\end{array}$ & $\begin{array}{c}\text { Number } \\
\text { of people }\end{array}$ & Percentage & $\begin{array}{c}\text { The use of class-based } \\
\text { multimedia }\end{array}$ & $\begin{array}{c}\text { Number of } \\
\text { people }\end{array}$ & Percentage \\
\hline Listen & 18 & $20 \%$ & Lesson guide & 47 & $52.2 \%$ \\
\hline Say & 11 & $12.2 \%$ & $\begin{array}{c}\text { Language point } \\
\text { explanation }\end{array}$ & 36 & $40 \%$ \\
\hline Look & 73 & $81.1 \%$ & Exercise & 12 & $13.3 \%$ \\
\hline Take notes & 25 & $27.8 \%$ & Grammar & 11 & $12.2 \%$ \\
\hline & & & Vocabulary & 16 & $17.8 \%$ \\
\hline & & & Additional knowledge & 48 & $53.3 \%$ \\
\hline
\end{tabular}

Table 7 shows, in English Multimedia Teaching high school students to do most is to see and write, teachers in teaching or to impart knowledge based, hear and speak no more in the classroom exercise, this approach does not ignore heard conducive to the formation of students 'language skills, is not conducive to the development of a variety of smart students, students' reading levels slightly increased while the level of hearing did not improve, or even decline. Now most of the Chinese students' English listening than reading ability is weak, multimedia teaching seems lame to make this phenomenon become more serious. On the multimedia applications of class type, the number of students selected for the project from more to less, respectively, guide lesson, complementary knowledge, to explain the language points, vocabulary, and grammar exercises; on the teacher's option results: guide Lesson, additional knowledge, vocabulary, language points to explain, exercises and grammar (seen from table 5). After the contrast can be seen, for teachers and students in the multimedia applications of this class, the view is basically the same.

Table 8 based language like English classes to explain the point of (multiple choice, 90)

\begin{tabular}{c|c|c|c|c|c}
\hline Classification & $\begin{array}{c}\text { Teachers } \\
\text { explain, } \\
\text { writing on the } \\
\text { blackboard }\end{array}$ & $\begin{array}{c}\text { The teacher } \\
\text { explained, } \\
\text { multimedia } \\
\text { edge demo }\end{array}$ & $\begin{array}{c}\text { Multimedia } \\
\text { demo, make } \\
\text { notes }\end{array}$ & $\begin{array}{c}\text { Teachers flexible and } \\
\text { vivid explanations, } \\
\text { necessary to use a } \\
\text { multimedia presentation }\end{array}$ & $\begin{array}{c}\text { To speak } \\
\text { in the } \\
\text { papers }\end{array}$ \\
\hline $\begin{array}{c}\text { Number of } \\
\text { people }\end{array}$ & 13 & 26 & 7 & 82 & 17 \\
\hline Percentage & $14.4 \%$ & $28.9 \%$ & $7.8 \%$ & $91.1 \%$ & $18.9 \%$ \\
\hline
\end{tabular}

Table 8 shows, like English class type of language to explain the point, students like the teacher-student interaction, interactive teaching-related options, and multimedia in the teaching process which must be secondary position. Although there are advanced technology, the existence of distance education, but the role of teachers can not be replaced, because people need to communicate and exchange. $14.4 \%$ of the candidates "teachers, writing on the blackboard" is due mainly multimedia applications, teachers rarely use the traditional method of imparting knowledge, students and teachers choose teaching is consistent. Teacher quality level of discourse often directly influence and determine the success or failure of classroom teaching quality. 91.1\% of the figure can be seen in the media to explain the language points should play a finishing touch.

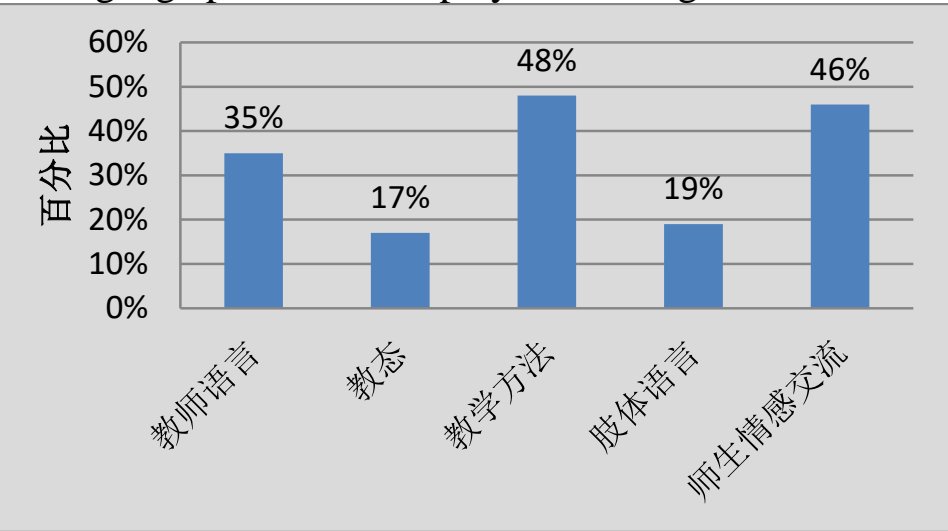

Fig.4 The multimedia instructional factors (multiple choice, 90) 
Figure 4 show that multimedia is a double-edged sword. Therefore, the quality of the teachers themselves can decide this double-edged sword is the advantages outweigh the disadvantages, or more harm than good. There are more important factors than the media in the teaching process, such as teaching methods. The teachers and students to participate in interactive classroom is student favorite. The only way to be better teachers and students of emotional communication, but only in the atmosphere of a good teacher-student relationship, teachers can better teach students better learning. $97 \%$ of the students admitted because like classroom teachers teach subjects they like, $86 \%$ of students admitted because of hate and give teachers teach subjects they are learning. Visible, good teacher-student relationship is very important. Language is a bridge, so the teachers to teach the language plus a good state and body language, so that students in a relaxed humor, clear the construction of new knowledge.

\section{Role orientation of teachers in Multimedia Assisted English Teaching}

Multimedia teaching English to bring such a huge change, English teachers should also be changed accordingly Role happen, the only way to give full play to the advantages of multimedia teaching. The role of teachers of English multimedia teaching environment should be:

1) Correctly understand the role of multimedia in Multimedia English Teaching

Multimedia in teaching is to play a supporting role, classroom teaching tool. All, it is only to further improve and develop the traditional teaching methods multimedia teaching is not teaching, not what courses like multimedia, but not each text is suitable for the use of multimedia to teaching. Multimedia applications only where they are needed, only the critical moment of inspiration, in order to effectively mobilize the students' enthusiasm and innovative spirit in order to effectively focus Overcoming Difficulties. Use of multimedia is to tap in the context of language teaching point, in order to "activate Textbook" to create a real scenario, so that students are actively involved in teaching, learn to think in English, with English expressions.

Teachers must play a leading role of teachers. In English class, the teacher has a lot of action is multimedia technology functions irreplaceable. Although multimedia is the most advanced modern teaching tool, it is only an auxiliary tool for teaching one, can only play the role of teaching service. The teacher should make full use of multimedia educational resources and textbooks, multimedia aids, student-centered, teacher-led, guide students to actively explore learning.

2) Multimedia and traditional English teaching English teaching combine

Although there are a variety of English teaching methods, many teachers continue to use the traditional English teaching methods, which undoubtedly wise enough not their professional judgment. Other teachers, but also use the traditional teaching methods, but also a reasonable application of multimedia.Teachers in teaching must be the appropriate choice of teaching methods based on the current teaching objectives, reasonable use of multimedia. Combination of English teaching and multimedia technology will make a difference in the field of traditional teaching powerless. Reasonable application of multimedia can supplement traditional teaching deficiencies, improve teaching quality, optimize classroom teaching, the ability to help students and keep students interested. To avoid the use of multimedia content from textbooks, students simply to interest-based formalism, but to the "timely, appropriate and adequate" principle, identify the point of integration with multimedia teaching content, pay attention to audio-visual integration. The problem of solving the traditional English class teaching is less information and the density is small. Multimedia classroom teaching "new, diverse, authentic English environment" and other aspects of traditional teaching unparalleled advantages in creation.In teaching practice, teachers often form their own inherent for students to adapt teaching style. On the use of multimedia, the production of courseware, teachers should be integrated into their own style, so not only reflect their own teaching ideas, but also easy to let students to receive.

3) Pay attention to the interaction between teachers and students in Multimedia Teaching

Natural language between people is the most affinity, the most flexible language classroom interactive communication between teachers and students should be the most effective way of 
teaching and learning. Classroom interaction influences the effectiveness of classroom teaching by influencing the classroom atmosphere, the feedback in the classroom and the student's participation degree. In teaching teachers should use more conversation exchanges as an important form of teaching, in order to facilitate between teachers and students as well as students interact better. The classroom teaching is not a unified model, teachers should change the teaching object on the basis of changing teaching methods, the overall plan, guide the students to timely carry out all kinds of teaching activities, so as to give full play to the leading role of teachers, students as the main body of the teaching activities, enable students to participate in the classroom. If teachers in the use of multimedia teaching, attention to student feedback, and timely language or eye contact, so that students will have paid attention to the feeling, the enthusiasm of study will be excited. Even the use of multimedia can also create emotional exchanges and natural infiltration. Respect comply with internal development needs of students, students' attention to the development of innovation and collaborative learning; emphasizes teaching and learning, teacher-student interaction, and strive to create a democratic atmosphere in the classroom, and effectively improve teaching effectiveness, teachers should try to praise, encourage students to give their huge motivation. Classroom Teaching is a subtle psychological collision between teachers and students as the main feature of emotional communication.

4) Focus on outstanding multimedia courseware in the classroom teaching role

Teachers in the preparation of multimedia courseware, the courseware should be noted that the autonomy that the courseware should be targeted, openness, cooperation, situation. Making excellent high-quality multimedia courseware, you need: (1) teaching materials, teaching methods and teaching accurately grasp objects, a deep understanding of the teaching process; (2) related multimedia technology. If the teacher is not thorough to the teaching practice, not seriously study the teaching syllabus, teaching materials, teaching methods, to understand the actual situation of the students, even if there is a multimedia production of highly skilled, it is difficult to develop excellent courseware. But in seeking common multimedia courseware, it must also reflect the personality characteristics, which requires teachers to have a certain multimedia technology. In the process of making multimedia courseware to determine the courseware is for classroom teaching service principle, courseware should not focus on the colorful pictures, vivid animation, but should focus on to stimulate student interest in learning beyond the traditional limitations of the media, becomes the abstract image, to simplify, to better help students break through the key and difficult to improve classroom efficiency, optimize teaching. Multimedia courseware production to grasp the trend in a positive direction of development should play a teacher's personality characteristics and teaching, choice of teaching resources needed to select the appropriate presentation of information and appropriate teaching strategies, but also the use of Internet resources to create optimal learning environment for students, personalized education. Mining existing teaching resources, open up a new teaching model, in the production of courseware, might be some "empathy", the teacher put the students 'perception point of view, the students placed courseware master status, to understand students' learning and mood learning psychology, so that students understand the language training and continue to master the materials, and then use, to think in English and expression level. Teachers should continue to accumulate experience in exploration efforts making skills, create more illustrations, phonetic superb excellent multimedia courseware, teaching efforts to obtain the best results.

\section{Summary}

In summary, in English classroom teaching, English teachers should identify the role of multimedia in teaching and learning environment, timely and reasonable use of multimedia technology, the creation of learning English context, to solve problems related to teaching English teaching and other audio-visual, audio-visual perception by students of English limited classroom full of students at the same time play the leading role of teachers, students play the subjectivity and creativity, in order to guide students in quantity and quality of listening, speaking, reading and writing 
training to enable; language materials, develop listening skills while access to basic knowledge of English, the language skills of basic training, culture directly in English thinking and presentation skills to use, and lay a solid foundation for the realization of communication in English. Thus, to achieve the introduction of modern teaching methods to classroom teaching English to the real purpose.

\section{References}

[1] L.H. Hou, traditional teaching and innovative teaching in vocational English teacher role localization studies [D], Guangzhou: Zhongshan University, 2008: 1-12.

[2] R.M. Zhang, comment College English Multimedia Teaching and Learning Strategies [J]. Foreign Language Teaching, 2000, 4 (5).

[3]C. Na, Computer Aided English Teaching Courseware [J]. Basic education foreign language teaching and research, 2001 (5-6).

[4] W.J. Duan, Sun Chunling, the advantages of Multimedia Assisted English teaching, misunderstanding and Countermeasures [J], Journal of Zhongshan University (NATURAL SCIENCE EDITION), 2003, 42 (2): 261-265.

[5] C.H. Yang, on the characteristics of multimedia computer assisted English teaching [J], foreign language teaching: 46 (1).2000 - 47.

[6] S.F. Zhao, L. Song, play the advantages of multimedia courseware to improve English Teaching //" College English Intensive Reading "Multimedia courseware assisted English Teaching of [J]. Language, 1999 (2).

[7] D.X. Ning, college English teachers in converting multimedia assisted teaching and learning environment Role [J], Luoyang University, 2007,22 (3): 127-128.

[8]G.X. Liang, the role of teachers in the use of multimedia assisted English teaching position [J], read count, 2012,2 (10): 235-236.

[9]H.J. Gao, the use of multimedia computer aided Foreign Language Teaching feasibility study [D], Liaoning Province: Liaoning Normal University, 2003: 7-16.

[10] X.H. Zhang. Foreign Language Teaching from the traditional to the Computer Assisted Language Learning [J]. Basic English Education, 2003 (2). 